Karolina Chmielecka

(Szkoła Wyższa Psychologii Społecznej w Warszawie)

\title{
Relatywizm kulturowy w procesie kształtowania się ocen moralnych - o percepcji kłamstwa w kulturze zachodniej i chińskiej
}

\author{
Nie ma wogóle zjawisk moralnych, \\ lecz tylko moralna interpretacja zjawisk
}

(F. Nietzsche $)^{1}$

Pod koniec 2006 r. odbyła się w Chicago konferencja The Plastics News China Forum ${ }^{2}$, która miała na celu dostarczenie amerykańskim biznesmenom informacji ułatwiających odniesienie sukcesu na rynku chińskim. Ponieważ obecnie rynek chiński jest uważany za jeden z najbardziej obiecujących, co roku organizuje się setki tego typu konferencji na całym świecie. Konferencja, o której mowa szczególnie jednak zwróciła uwagę środowiska biznesowego (zarówno amerykańskiego, jak i chińskiego) z powodu kontrowersyjnego wystąpienia Janet Carmosky, przewodniczacej China Prospects. Janet Carmosky swoje zaledwie 24 minutowe wystapienie poświęciła m.in. problematyce kłamstwa, a dokładniej przyczynom kulturowym, świadczącym o odmiennej jego percepcji w kulturze chińskiej i amerykańskiej. Wystąpienie wywołało burzliwą dyskusję. Na kilkunastu forach moderowanych przez osoby współpracujące z Chińczykami toczyła się gorąca dyskusja na temat wspomnianego wystąpienia. Wypowiedź Carmosky uznano za obraźliwą i stereotypową. Negatywna reakcja słuchaczy miała jednak niewiele wspólnego z treścią wystąpienia. Przewodniczącą China Prospects skrytykowano za sam fakt poruszenia na China Forum tak delikatnego i niewygodnego zagadnienia, jakim jest brak zaufania wobec chińskich partnerów biznesowych. W ten sposób wystapienie Carmosky, które miało na celu obalenie stereotypów, paradoksalnie zostało uznane za propagujące stereotypowy sposób postrzegania kultury chińskiej. Ostatecznie uczestnicy dyskusji, opierając się w wielu wypadkach na absurdalnych założeniach (np. wydarzenia

\footnotetext{
${ }^{1}$ F. N i e t z s c h e, Poza dobrem i złem, Zielona Sowa, Kraków 2005, s. 77.

${ }^{2}$ The Plastics News China Forum. Practical Advice for Plastics Processors, „Suppliers \& Managers", 14-15 listopada 2006, www.plasticsnews.com/chinaforum/index.html (stan z 18.11.2006).
} 
historyczne, mające miejsce w Chinach w przeciagu ostatnich 60 lat nie mają związku z kulturą chińską; skoro nie każdy przedstawiciel kultury zachodniej jest chrześcijaninem, to nie możemy twierdzić, że dana religia miała wpływ na system wartości przyjęty na Zachodzie) doszli ostatecznie do wniosku, że „może powinniśmy jednak zając się ekonomią zamiast studiowania antropologii" ". Uczestnicy dyskusji zgodni byli także co do stwierdzenia, że kulturze amerykańskiej obce jest kłamstwo i brak zaufania, ponieważ przestrzegana jest w niej litera prawa. Stwierdzili także, że korupcja i guanxi znikną z kultury chińskiej, gdy tylko wzrośnie rola prawa w Chinach. Uznali, że Chiny po prostu potrzebuja czasu na naukę prowadzenia biznesu według prawa międzynarodowego, które jest bardzo dobrze znane i przestrzegane na Zachodzie. Zatem wychodząc z założenia, że nie należy mówić o kulturze, lecz o konkretnych jednostkach, bo ludzie są różni, a postrzeganie ich poprzez pryzmat wartości, skrypty zachowań i normy przypisane danej kulturze stereotypizuje ich zachowania, dyskutanci doszli ostatecznie do wniosku, że Chińczycy po prostu muszą jeszcze sporo się nauczyć od Amerykanów. Dany przykład pokazuje, w jaki sposób zwykło się dyskutować na Zachodzie na temat kwestii dotyczących moralności. Relatywizm kulturowy, czyli założenie, że żadna praktyka kulturowa sama w sobie nie jest ani zła ani dobra, ale musi być oceniona w kontekście kultury, w której funkcjonuje - należy obecnie do poglądów szeroko rozpowszechnionych nie tylko w środowisku kulturoznawców. Uważa się bowiem, że przyjęcie tego typu założenia świadczy o otwartości, tolerancyjności i dojrzałości badacza. Uczymy się zatem jeść pałeczkami i podawać wizytówkę trzymając ją w obu rękach. Jesteśmy w stanie zaakceptować cały szereg norm, które były nam wcześniej obce, a teraz, gdy mamy styczność z kulturą chińską i nie chcemy zostać uznani za ignorantów, staramy się im podporządkować. Jednak nasza otwartość i tolerancyjność zazwyczaj kończy się tam, gdzie „,nowości” zaczynają podważać nasz system wartości. Gdy wchodzimy w obszar problematyki moralności, pojawia się dysonans poznawczy. Nowy system wartości staje się niemożliwy do zintegrowania $\mathrm{z}$ silnie zinternalizowanym i w dużym stopniu nieświadomym systemem wartości, będącym efektem socjalizacji, a tym samym kultury, która nas ukształtowała. Zamiast integracji pojawia się polaryzacja poglądów i degradacja systemu wartości, który jest nam obcy. W ten sposób uznajemy wyższość systemu wartości preferowanego przez naszą kulturę i w kontekście danego systemu zaczynamy analizować, a co ważniejsze - oceniać obcą nam kulturę. Nad moralnością w kulturze zachodniej nie dyskutuje się, bo z perspektywy chrześcijańskiej moralność jest wspólna wszystkim ludziom. Podjęcie dyskusji na dany temat i podważenie pewnych norm, uznawanych przez zachodni absolutyzm moralny za niezmienne uchodzi za przejaw podwójnej moralności, co jest na Zachodzie równoznaczne z byciem niemoralnym. Mimo że prawdopo-

\footnotetext{
${ }^{3}$ www.chinalawblog.com/chinalawblog/2006/11/is_there_such_a.html.
} 
dobnie każdy, kto miał do czynienia z kulturą chińską, spotkał się z powszechnie powtarzanym stwierdzeniem, że Chińczycy kłamią i nie należy im ufać, to uważa się, że na dany temat nie wypada rozmawiać. Janet Carmosky, podsumowując dyskusję na China Law Blog stwierdza: „Podczas mojego przeszło dwudziestoletniego pobytu $\mathrm{w}$ Chinach wielokrotnie spotykałam się ze stwierdzeniem amerykańskich turystów, studentów, wykładowców akademickich, biznesmenów, ekspatriotów, członków Kongresu i przedstawicieli rządu, że czują się oszukani przez Chińczyków. Czy w każdym z tych przypadków źle zrozumiałam mojego rozmówce? Jeśli nie, to dlaczego jestem oskarżana jako jedyna o obrazę Chińczyków?". Zatem albo możemy nadal uznawać temat moralności za tabu, albo spróbować zastanowić się, co jest przyczyną nieporozumień, konfliktów i wzajemnych oskarżeń. Celem niniejszego artykułu jest próba przyjrzenia się różnicom kulturowym, które mogą stanowić o odmiennym sposobie percepcji kłamstwa w kulturze chińskiej oraz zachodniej ${ }^{4}$.

\section{Zdrowy rozsądek vs. logika formalna}

Lin Yutang, pisarz i zarazem autor prac zawierających trafne międzykulturowe porównania, stwierdza: „Chińska logika opiera się na chińskiej koncepcji prawdy”. Następnie dodaje: „Prawda, według Chińczyków, nigdy nie może być udowodniona. Może być tylko zasugerowana" ${ }^{6}$. Z punktu widzenia zachodniego sposobu postrzegania logiki powiedzielibyśmy raczej, że chiński styl myślenia jest po prostu pozbawiony logiki. Rzeczywiście logika w rozumieniu zachodnim (oparta na Arystotelesowskich zasadach) nigdy tak naprawdę nie przyjęła się na gruncie kultury chińskiej. Z tego powodu, Chińczycy przyczynili się do rozwoju algebry i arytmetyki, ale ich wkład w geometrię, która polega na logice formalnej, jest znikomy. Zatem na czym polegają Chińczycy, jeżeli nie na logice? Otóż „zamiast polegać na logice, która nigdy nie stała się dziedziną nauki, wolą polegać na zdrowym rozsądku"”. W języku chińskim termin qingli (rozsądek/rozsądny) składa się z dwóch członów: qing (renqing), czyli natura człowieka/prawdziwe uczucia i li (tianli), czyli niebiański porządek/odwieczne zasady. „Qing reprezentuje zmienny, dostosowujący się do okoliczności czynnik ludzki, a li reprezentuje niezmienne zasady rządzące wszechświatem" ". Zatem, według Chińczyków, rozsądny człowiek wyciąga wnioski o prawdziwości zjawisk na podstawie zarówno wiedzy na temat świata, którą już dysponuje, jak i kontekstu

\footnotetext{
${ }^{4}$ Przyjmuję wstępnie określenie kultura zachodnia, bowiem będę odwoływać się zarówno do badań amerykańskich, kanadyjskich, brytyjskich, jak i polskich.

${ }^{5}$ L. Y u t a ng, My Country. My People, Foreign Language Teaching and Research Press, Beijing 2000, s. 86.

${ }^{6}$ Ibidem, s. 86 .

${ }^{7}$ Ibidem, s. 87.

${ }^{8}$ Ibidem, s. 89.
} 
sytuacyjnego. Jako że kontekst jest zmienny, to nie można orzekać o pewnych wartościach stałych rzeczy lub zjawisk. Zatem to, co było prawdą, może okazać się kłamstwem, a to co było kłamstwem, może stać się prawdą. Ocena jest zależna od perspektywy, z jakiej analizujemy dane zjawisko. W drugim rozdziale Zhuangzi, zatytułowanym Qiwulun (czyli $O$ wyrównywaniu przeciwieństw) powiedziane jest: „Przypuśćmy, że się z tobą spieram i żeś ty mnie zwyciężył, a ja nie zwyciężyłem ciebie; czyż koniecznie nie mam mieć racji? A jeśli ja ciebie pokonam, a ty mnie nie, czyż koniecznie muszę mieć słuszność, a ty zupełnie nie? Czyż [koniecznie] jeden ma rację, a drugi jej nie ma? Czy też obaj mamy rację albo obaj jesteśmy w błędzie? Kiedy my nie możemy o sobie wzajemnie nic wiedzieć, to inni na pewno też są w ciemnościach. Kogóż mam wezwać na sędziego? Wezwę takiego, co się z tobą zgadza; skoro tak, jakżeż może nas sądzić? Wezwę takiego, co się ze mną zgadza; skoro tak, jakżeż może nas sądzić? Wezwę takiego, co się z żadnym nie zgadza; skoro tak, jakżeż mo że nas sądzić? Wezwę takiego, co się z nami oboma zgadza; skoro tak, jakżeż może nas sądzić?" Zhuangzi utrzymuje zatem, że pojęcie słuszności i błędności każdy człowiek konstruuje na podstawie własnego punktu widzenia. Zatem może być wiele poglądów na jedną i tę samą rzecz. To, co jeden uznaje za prawdę, dla innego może być kłamstwem. Na odmienność logiki chińskiej od zachodniej miały wpływ przede wszystkim specyficzne warunki historyczne, społeczne i kulturowe. Pamiętać bowiem należy, że podstawy zachodniej logiki ukształtowały się w starożytnej Grecji, w kraju, w którym swobody obywatelskie i przyzwolenie na prowadzenie publicznej debaty umożliwiły swobodną ekspresję myśli i prowadzenie otwartej dyskusji. Z tego powodu zwykło się określać kulturę grecką jako kulturę żywego słowa. „W kulturze greckiej o wartości człowieka świadczyło nie tylko, jakim jest wojownikiem, ale także jakim jest mówcą" 10 . To właśnie z tego okresu pochodzi słynna formuła Katona Starszego: „Mówca to człowiek prawy, biegły w mówieniu” (Orator est vir bonus, dicendi peritus). Starożytni Grecy, ćwicząc się w prowadzeniu debat i ucząc się wyciągania wniosków na podstawie sylogizmów, uznali logikę za narzędzie niezbędne do prowadzenia sporów retorycznych. Posiadając odpowiednie doświadczenie i właściwy zasób terminologii niezbędnej do posługiwania się logiką wywodu akceptowali prawdę jedynie w przypadku, gdy została poparta dowodami natury rozumowej lub empirycznej. Podczas, gdy starożytni Grecy poznawali zalety i wady nadanych im swobód obywatelskich, Chińczycy pozostawali wierni filozofii Konfucjańskiej, która interes grupy stawiała przed indywidualnymi potrzebami jednostki. Wartość, jaką nadawano zachowaniu harmonii w grupie i hierarchiczność społeczeństwa wykluczała możliwość podej-

${ }^{9}$ F. Y o u 1 a n, Krótka historia filozofii chińskiej, PWN, Warszawa 2001, s. 129.

${ }^{10} \mathrm{R}$. E. N i s b e t t, The Geography of Thought. How Asians and Westerners Think Differently... and Why, The Free Press, Nowy Jork, 2003. 
mowania jakichkolwiek publicznych debat ${ }^{11}$. Z tego powodu w Chinach nigdy nie rozwinął się język charakterystyczny i niezbędny do prowadzenia otwartej dyskusji i publicznej krytyki. Nadal powszechnie uważa się w Chinach, że należy unikać jakiejkolwiek bezpośredniej konfrontacji, ponieważ może ona zburzyć ustanowiony ład społeczny. Nie mogąc udowodnić prawdy poprzez wywód logiczny, Chińczycy przyjęli kontekst sytuacyjny jako główny miernik oceny. Poza tym uznali, że prawda sama musi się obronić. W Chinach powszechnie przyjmuje się założenie, że „Prawdy nie trzeba udowadniać, ponieważ ujawni się sama" 12 .Chińczycy nie mają $\mathrm{w}$ zwyczaju udowadniania swoich racji poprzez rozprawy naukowe składające się z dziesięciu czy nawet pięciu tysięcy słów. Przygotowują jedynie krótką zwięzłą informację, która może zostać uznana lub obalona przez innych badaczy"13.

\section{Styl myślenia holistyczny vs. styl myślenia analityczny}

Odmienny sposób postrzegania logiki w kulturze chińskiej i zachodniej przyczynił się do powstania dwóch odmiennych stylów myślenia - holistycznego w Chinach i analitycznego w kulturze zachodniej. Na sposób myślenia Chińczyków oprócz braku logiki, typowej dla kultury zachodniej, miał także wpływ specyficzny sposób postrzegania świata. Otóż, według Chińczyków, rzeczywistość pozostaje w stanie ciagłych przemian. Skoro nic nie jest stałe, to tym samym błędne jest orzekanie o pewnych stałych cechach zjawisk bądź rzeczy. Takie założenie wyklucza możliwość polaryzacji poglądów, więc uznaje za niemożliwe formowanie się przeciwieństw. Zatem zakłada się, że nie istnieją dwie całkowicie przeciwstawne kategorie kłamstwa i prawdy. Każde kłamstwo może zawierać $\mathrm{w}$ sobie pierwiastek prawdy, a każda prawda może zawierać w sobie coś z kłamstwa. Który z aspektów danego wymiaru (kłamstwo czy prawda) przeważy w danym układzie, zależne jest od kontekstu sytuacyjnego i skończonego punktu widzenia osoby oceniającej. Na tej podstawie wyróżniono trzy zasady ${ }^{14}$, które wywarły ogromny wpływ na ukształtowanie się holistyczne-

${ }^{11} \mathrm{~W}$ latach $600-200$ p.n.e. miały miejsce sporadyczne debaty, ale brali w nich udział jedynie wybrani filozofowie.

${ }^{12}$ G. G a o, S. T i n g - T o o me y, Communicating Effectively with the Chinese, Sage Publications, London 1998.

${ }^{13}$ L. Y u t a n g, op. cit., s. 87.

${ }^{14}$ Odnosząc te zasady do zagadnienia prawdy i kłamstwa, należałoby zinterpretować je w następujący sposób: zasada zmiany - stwierdzenie fałszywe może się stać prawdziwym, a prawdziwe fałszywym; zasada sprzeczności - każde stwierdzenie może być jednocześnie prawdziwe i fałszywe; zasada relacyjności - każde stwierdzenie zyskuje etykietę prawdziwego lub fałszywego (lub zarówno prawdziwego, jak i fałszywego) poprzez kontekst sytuacyjny (uwaga autora). 
go systemu myślenia w Chinach: zasadę zmiany (bian yi lu), sprzeczności ${ }^{15}$ (mao dun lu) oraz relacyjności (zheng he $l u)^{16}$. Odzwierciedleniem tych zasad jest symbol taiji, w którym współistnieją i przenikają się wzajemnie dwa pierwiastki, często w kulturze zachodniej błędnie określane jako przeciwstawne siły. Każdy bowiem z danych pierwiastków zawiera w sobie cząstkę drugiego, co symbolizuje jedno $\mathrm{z}$ podstawowych założeń filozofii chińskiej - negację dualizmu. Taiji symbolizuje zasadę sprzeczności (współistnieją w nim dwa pierwiastki, a nawet każdy z nich zwiera w sobie element drugiego) oraz zasadę holizmu (pierwiastki są od siebie zależne poza tym dopiero gdy występują razem możemy mówić o harmonii). W przypadku kultury zachodniej mamy do czynienia z diametralnie odmiennym sposobem postrzegania świata.

Kultura zachodnia zawdzięcza rozwój logiki Arystotelesowi, który jest autorem trzech zasad ${ }^{17}$, świadczących o odmienności zachodniego stylu myślenia. Należą do nich: prawo tożsamości, wyłączonego środka i niesprzeczności. Według Arystotelesa, sąd nie może być zarazem prawdziwy i fałszywy. Zasady ustanowione przez Arystotelesa przyczyniły się do polaryzacji poglądów, która z kolei dała początek kategoryzacji obiektów i zjawisk oraz generalizacji przypisywanych im cech. Starożytni Grecy zapoczątkowali pewien specyficzny dla Zachodu sposób postrzegania rzeczywistości. Wyszli oni bowiem z założenia, że wszystko można zbadać, a tym samym uznali, że większość zjawisk charakteryzuje stałość lub powtarzalność w czasie. Co więcej, uznali także, że dane zjawiska i rzeczy można badać oddzielnie, zatem kontekst nie jest istotny dla oceny wybranego zjawiska. Stąd w kulturze zachodniej przyjęła się klasyczna zasada kłamstwa, tzn. kłamstwem jest to, co nie jest zgodne z rzeczywistością. Kłamstwo i prawda są pewnego rodzaju monolitem znaczeniowym. Ich wartość pozostaje niezmienna bez względu na kontekst, w jakim są interpretowane.

${ }^{15}$ Jednym z ciekawszych przejawów praktykowania przez Chińczyków zasady sprzeczności jest chiński synkretyzm religijny. Wśród różnych bóstw czczonych w świątyniach taoistycznych możemy także znaleźć chrześcijański posąg św. Jana, buddyjskie posagi Awalokiteśwary i Sakjamuniego, a nawet posag jednego z najbardziej znanych XI-wiecznych dowódców wojskowych Yue Fei. O łączeniu buddyzmu z taoizmem może natomiast świadczyć umieszczanie w buddyjskich świątyniach posagów Guandi razem z taoistycznymi wróżbitami, przepowiadającymi przyszłość. Mistrz zen praktyki te podsumował w następujący sposób: „Dla ludzi o wielkiej mądrości religie te są takie same, a dla ludzi o małych możliwościach intelektualnych - różne. Oświecenie i złudzenie zależą jedynie od zdolności człowieka, a nie od różnic w nauczaniu”. Cyt. za: H. N a k a m u ra, Systemy myślenia ludów Wschodu, Wydawnictwo Uniwersytetu Jagiellońskiego, Kraków 2005, s. 284.

${ }^{16}$ K. P e n g, R. E. Nis bett, Culture, Dialectics, and Reasoning About Contradiction, „American Psychologist” 1999, Vol. 54, No. 9, s. 741-754.

${ }^{17}$ Prawo tożsamości - stwierdzenie prawdziwe zawsze jest prawdziwe a stwierdzenie fałszywe zawsze jest fałszywe; prawo wyłączonego środka - stwierdzenie może być albo prawdziwe albo fałszywe; prawo niesprzeczności - stwierdzenie nie może być jednocześnie prawdziwe i fałszywe, [za:] K. P e n g, R. E. N i s b e t t, op. cit., s. 741-754. 
Według Chińczyków, zasada niesprzeczności przyjęta w zachodnich kulturach jest całkowicie abstrakcyjnym twierdzeniem, które nie ma nic wspólnego z otaczającą nas rzeczywistością. Uważają bowiem, że analizowanie wyrwanych z kontekstu zjawisk świadczy o braku doświadczenia i niedojrzałości badacza. W kulturze zachodniej uważa się z kolei, że kierowanie się jedynie intuicją zamiast dowodami natury empirycznej świadczy o naiwności. O tym, że odmienne style myślenia zdominowały właściwie wszystkie dziedziny nauki, zarówno w Chinach, jak i w kulturze zachodniej, świadczyć mogą zarówno odmienne odkrycia, przypisywane określonym kulturom, jak i forma, jaką w obu kulturach przyjęła medycyna. Otóż Grecy przyczynili się do rozwoju geometrii, logiki formalnej, historii naturalnej i etnografii, natomiast Chińczycy, według których wszystkie zjawiska pozostają w stanie wzajemnej zależności, odkryli kompas magnetyczny, sejsmograf, wybudowali pierwszy system irygacyjny, przyczynili się do rozwoju kartografii, a także zwrócili uwagę świata na zjawisko akustyki. W medycynie różnica pomiędzy poglądami Chińczyków i przedstawicieli kultury zachodniej polegała przede wszystkim na tym, że ci pierwsi właściwie prawie w ogóle nie praktykowali operacji chirurgicznych.

\section{Filozofia taoistyczna vs. religia judeochrześcijańska}

Na ukształtowanie się holistycznego i analitycznego stylu myślenia ogromny wpływ miały także systemy filozoficzne i religijne, typowe dla omawianych obszarów kulturowych. Tym samym kluczem do zrozumienia koncepcji prawdy faworyzowanej w ramach danej kultury może okazać się także ich podłoże filozoficzno-religijne.

Filozofia taoistyczna myśleniu tylko w kategoriach ,tego, co leży w obrębie kształtów i cech" przeciwstawia założenie, że o naturze zjawisk i rzeczy decyduje nienazywalne dao. Dao jest tym, przez co wszystko, co nazywalne, staje się. Uznając dao za „rodzicielkę dziesięciu tysięcy rzeczy” Laozi tym samym manifestuje swoje zainteresowanie procesem odpowiedzialnym za stawanie się rzeczy i zjawisk, a nie ich kategoryzowaniem. Istotą filozofii taoistycznej jest także założenie, że świat podlega ciagłym przemianom. Dany proces jest możliwy dzięki założeniu o braku istnienia skrajności. Jedno z popularnych chińskich powiedzeń, stanowiące parafrazę słów Laozi, brzmi: „Kiedy rzecz osiaga skrajność, odwraca się od niej" ${ }^{18}$. Wyklucza się w ten sposób typową dla zachodniego systemu myślenia potrzebę zamknięcia. Jeżeli rzecz lub zjawisko przyjmuje skrajną formę, to automatycznie zmienia się w swoje przeciwieństwo. Skoro każda rzecz podlega ciagłemu procesowi przemiany, to nie można mówić o stałych i charakterystycznych dla niej atrybutach. Jeżeli rzeczy czy zjawiska nie wyróżnia konkretny zbiór cech, to jakiekolwiek kategoryczne oceny nie mają

\footnotetext{
${ }^{18}$ F. Y o u l a n, op. cit., s. 112.
} 
sensu. Zatem, według taoistów, nie istnieje kategoria zła i dobra absolutnego ${ }^{19}$. Każda ocena jest względna i subiektywna. Laozi powiada: „Gdy cały świat uznał piękno za piękno, wtedy [pojawiła się] szpetota. Gdy wszyscy uznali dobro za dobro, wtedy [powstało] zło" ${ }^{20}$. Rzeczy zawsze podlegają zmianom i mają wiele aspektów. Zatem może być wiele poglądów na jedną i tę samą rzecz. Laozi wyraźnie faworyzuje tych, którzy pojęli zasadę dao, powiada bowiem: „Będąc bezstronnymi, zdobywają dostojeństwo królewskie”21. Powstrzymanie się od wydawania sądów absolutnych jest zatem w kulturze chińskiej bardzo wysoko cenione.

Na ukształtowanie się charakterystycznego dla kultury zachodniej dualizmu ogromny wpływ miała religia judeochrześcijańska ${ }^{22}$. Przeciwieństwa typu dobro vs. zło, ciało vs. dusza, Bóg vs. Szatan, niebo vs. piekło to produkt zachodniego dualizmu etycznego. Prawo wyłącznego środka także odpowiada danemu stylowi myślenia. Jednak religia judeochrześcijańska uznała istnienie odrębności prawdy i kłamstwa, obu tym kategoriom nadała określoną wartość. Kłamstwo zrównała z grzechem. „Kłamstwo jest grzechem. Język (mowa) został dany człowiekowi po to, aby wyrażając nim prawdę potwierdzał ład stworzenia, którego twórca, zarówno w aspekcie treściowym, jak i przede wszystkim egzystencjalnym - jest Bóg, ${ }^{23}$. Zatem kłamstwo zostaje uznane za niedozwolone nie tylko ze względów moralnych, lecz także teologicznych. Tym samym poddane zostaje podwójnemu ostracyzmowi. Arystoteles wprowadza absolutny zakaz kłamania. Rozróżnieniu na kłamstwo i fałsz towarzyszy także wprowadzenie rozgraniczenia między „,człowiekiem prawdziwy” (chrześcijaninem) a „człowiekiem nieprawdziwym" (ateistą lub innowierca). W ten sposób dochodzi do nałożenia się dwóch kategorii, czego rezultatem jest założenie rodowodu herezji w kłamstwie. Zatem ,prawdziwym człowiekiem” jest chrześcijanin, a jako że

${ }^{19}$ Koncepcja zła absolutnego jest także obca buddyzmowi chińskiemu chan, w którym przyjmuje się, że ,[...] istoty w piekle mogą osiaggnąć stan Buddy, a Budda w tym samym czasie może przejść do świata złudzeń. W takim świecie nie istnieje ani osoba absolutnie dobra, ani absolutnie zła". Żaden człowiek nie jest absolutnie zły i każdy ma możliwość dostąpienia zbawienia, jeśli tylko podejmie odpowiednie wysiłki w tym celu. Por. H. N a k a m u r a, op. cit., s. 115 .

${ }^{20}$ Ibidem, s. 116.

${ }^{21}$ Ibidem, s. 114.

${ }^{22}$ Termin judeochrześcijaństwo krytykowany jest za swoją zbyt dużą pojemność i nośność interpretacyjną. Jednak uważam, że w kontekście tego artykułu jego użycie jest jak najbardziej właściwe z co najmniej dwóch powodów. Po pierwsze, to właśnie Stary Testament piętnuje kłamstwo. Stary Testament jest nazywany Bibliq Hebrajskq i w oryginalnej wersji został zapisany w języku hebrajskim, który dysponuje największą liczbą terminów, określających grzech, a koncepcja grzechu i zbawienia opiera się na sposobie postrzegania kłamstwa. Po drugie, definicję korespondencyjną (nazywaną również klasyczna), zakładającą, że istotą prawdy jest zgodność z rzeczywistością sformułował filozof żydowski Izaak Ben Salomon.

${ }^{23}$ W. C h u d y, Filozofia ktamstwa, Oficyna Wydawnicza Volumen, Warszawa 2003, s. 352. 
religia chrześcijańska jest tą jedyną właściwą i prawdziwą, przyjęto za Sokratesem założenie, że prawda jest miarą człowieczeństwa. Normatywny kontekst stawiający barierę ludzkiemu kłamstwu wiąże się natomiast z ósmym przykazaniem Dekalogu: „Nie będziesz mówił fałszywego świadectwa przeciw bliźniemu swemu". W Piśmie Świętym odnajdujemy wiele przykładów piętnowania kłamstwa np. „Nie będziesz fałszywie przysięgał, lecz dotrzymasz Panu swej przysięgi” (Mt 5, 33), „Nie będziesz mówił przeciw bliźniemu swemu kłamstwa jako świadek” (Wj 20,16), „Niech wasza mowa będzie: Tak, tak; nie, nie. A co nadto jest, od Złego pochodzi". W kulturze zachodniej kłamstwo identyfikowane jest nie tylko z grzechem, lecz także ze złem. Jan Paweł II mówił w Olsztynie 6 czerwca 1991 r.: ,,[...] całe ludzkie postępowanie poddane jest wymogom prawdy. Prawda jest dobrem, a kłamstwo, fałsz, zakłamanie jest złem”"24. Taki sposób postrzegania kłamstwa miał także wpływ na ukształtowanie się klasycznej koncepcji kłamstwa w kulturze zachodniej, która zakłada, że kłamstwo nie zmienia swojej wartości w zależności od kontekstu.

\section{Kolektywizm vs. indywidualizm}

Prawdopodobnie nie ma takiego drugiego wymiaru, któremu poświęcono by tyle uwagi, ile kolektywizmowi i indywidualizmowi. Jednak to właśnie badania dotyczące relacji, w jakiej pozostaje jednostka wobec społeczeństwa przyczyniły się do powstania wielu generalizacji kulturowych, upraszczających, ale także wypaczających obraz kultury chińskiej. Dwubiegunowy podział na kultury kolektywistyczne i indywidualistyczne został wykreowany w kulturze zachodniej, która - jak już wcześniej wspominałam - ma tendencje do kategoryzowania, a tym samym polaryzacji poglądów. Podział dwubiegunowy przyczynia się do posługiwania się wartościami skrajnymi. John Greenwood ${ }^{25}$ zauważa, że aby można było kulturę chińską nazwać kolektywistyczną, musiałaby opierać się na koncepcji jednego z najbardziej aktywnych propagatorów marksizmu - Ai Siqi. Kultura zachodnia, aby została uznana za w pełni indywidualistyczną, musiałaby pozostać wierna filozofii Johna Stuarta Milla. Ani kultura chińska nie jest odzwierciedleniem poglądów Ai Siqi, bo Chińczycy z pewnością nie „poświęcają całego serca i dobrych chęci" ${ }^{26}$ w służbie swojemu narodowi, ani kultura zachodnia nie podporządkowała się myśli Milla, bo autonomia przedstawicieli kultury zachodniej z pewnością nie opiera się na całkowitej negacji jakichkolwiek więzi ze społeczeństwem. W każdej kulturze społeczeństwo dla jednostki

${ }^{24}$ Ibidem, s. 373.

${ }^{25}$ J. D. Green wood, Individualism and Collectivism in Mora land Social Thought, [w:] Kim-chong Chong, S or-hoon Tan, C. L. Te n, The Moral Circle and the Self, Open Court Publishing, Chicago 2003.

${ }^{26}$ Ibidem, s. 167. 
stanowi grupę odniesienia. Z badań Roberta Hymana wynika, że Amerykanie, tak jak Chińczycy, jako grupę odniesienia wskazują rodzinę, przyjaciół oraz grupę pracowniczą. Pozostaje zatem do rozstrzygnięcia tylko kwestia, w jakim stopniu grupa odniesienia ma wpływ na decyzje podejmowane przez jednostkę, a nie, czy w ogóle jest w jakiejś relacji z jednostką. Natomiast relacja, w jakiej jednostka pozostaje w stosunku do grupy ma ogromny wpływ na jej oceny moralne. Społeczeństwo chińskie postrzegane jest jako żywy organizm, w którym wszystkie zachodzące procesy są wzajemnie ze sobą powiązane. Każda jednostka jest zależna od innych ludzi, z którymi tworzy określone relacje. Dana grupa staje się także dla jednostki pewnego rodzaju zwierciadłem, tzn. ludzie, z którymi pozostaje $\mathrm{w}$ relacji, udzielają jej informacji zwrotnych, dotyczących wartości jej zachowania. Dane informacje są bardzo istotne dla Chińczyka nie dlatego, że - jak często sugerują zachodni badacze kultury chińskiej - Chińczycy nie mają wewnętrznego systemu wartości, dzięki któremu mogą ocenić swoje zachowanie, ale dlatego, że ogromnie istotne jest dla nich zachowanie harmonii w grupie. Osoby, z którymi Chińczycy wchodzą w interakcję zmieniają się, zatem to samo zachowanie może być w różny sposób przez różne osoby ocenione. Zatem rozsądniej jest wyciagać wnioski o prawdziwości zjawisk na podstawie zarówno wiedzy na temat świata, którą już dysponują, jak i kontekstu sytuacyjnego, w którym się znaleźli. Świadomość bycia elementem skomplikowanej sieci relacji międzyludzkich sprawia, że Chińczycy podejmują decyzje, które nie są dobre tylko z perspektywy jednostki, ale także z perspektywy grupy. Reguły współżycia w grupie określają zasady konfucjańskie. Z tego powodu uważa się, że o ocenie moralnej kłamstwa w kulturze chińskiej decydują przede wszystkim takie zasady, jak: zachowanie harmonii w grupie, przestrzeganie hierarchii, skromność i koncepcja zachowania twarzy ${ }^{27}$. O tym, że Chińczycy kategoryzując stwierdzenia jako prawdziwe lub fałszywe oraz nadając im określoną wartość moralną kierują się w dużym stopniu dobrem grupy świadczyć mogą chińsko-kanadyjskie badania Kang Lee ${ }^{28}$. Wynika z nich, że dzieci chińskie pod wpływem procesu socjalizacji uczą się przeobrażać wewnętrzne kategorie prawdy i kłamstwa zgodnie z oczekiwaniami społeczeństwa. Im są starsze, tym bardziej pozytywnie oceniają kłamanie w sytuacjach prospołecznych (nieprzyznawanie się do swoich dobrych uczynków). Siedmioletnie dzieci

${ }^{27}$ W badaniach chińsko-kanadyjskich Kang Lee Chińczycy najczęściej uzasadniali pozytywną ocenę kłamstwa w sytuacjach prospołecznych aprobatą dla przestrzegania zasady skromności. Z badań chińsko-polskich Karoliny Chmieleckiej (2007) wynika, że kłamstwo jest także oceniane przez Chińczyków pozytywnie w sytuacjach, w których wiąże się z ochroną osoby drugiej przed utratą twarzy i w sytuacjach, w których powiedzenie prawdy mogłoby przyczynić się do zaburzenia hierarchii społecznej, wynikającej z różnicy wieku i statusu.

${ }^{28} \mathrm{~K}$ a n g L e e et al., Taiwan and Manland Chinese and Canadian Children's Categorization and Evaluation of Lie- and Truth-Telling: a Modesty Effect, „British Journal of Developmental Psychology" 2001, Vol. 19, s. 525-542. 
chińskie, tak jak dzieci kanadyjskie, oceniają negatywnie kłamstwo i pozytywnie mówienie prawdy bez względu na kontekst sytuacyjny. Jednak już dzieci chińskie dziewięcio- i jedenastoletnie diametralnie różnią się w swoich ocenach moralnych od dzieci kanadyjskich. Zarówno dzieci siedmio-, dziewięcio- jak i jedenstoletnie tak samo jak dzieci kanadyjskie, etykietowały kłamstwo i prawdę. Dzieci chińskie w przypadku rozróżnienia kłamstwa i prawdy kierują się popularną na zachodzie klasyczną definicją kłamstwa. Zatem wśród dzieci nie zauważono różnic międzykulturowych, dotyczących umiejętności rozróżniania prawdy od kłamstwa, ale wartości moralnej, jaką się im nadaje w różnych kulturach. Jednak badania przeprowadzone przez Genue Fu ${ }^{29}$ wśród dorosłych Chińczyków pokazują, że wraz z wiekiem ulega zmianie nie tylko ocena moralna kłamstwa, lecz także etykieta. Wśród dorosłych Chińczyków aż 50\% badanych niemówienie prawdy w sytuacji prospołecznej etykietowało jako prawdę (!). Zatem wśród Chińczyków wraz z wiekiem nasila się zjawisko pokrywania się oceny moralnej z etykieta. W kulturze chińskiej negocjowana jest społecznie ocena moralna kłamstwa ${ }^{30}$, a nie sama etykieta kłamstwa (tzn.

\footnotetext{
${ }^{29} \mathrm{G}$ e n u e Fu et al., Chinese and Canadian Adult's Categorization and Evaluation of Lieand Truth-Telling about Prosocial and Antisocial Behaviours, „Journal of Cross-Psychology” 2001, Vol. 32, No. 6, s. 740-747.

${ }^{30} \mathrm{~W}$ przypadku badań nad kształtowaniem się ocen moralnych w kulturze chińskiej i zachodniej, badacze często powołują się na koncepcje Ruth Benedict (w dużym stopniu intuicyjna), która przyjmuje rozróżnienie kultury „winy” i kultury „wstydu”. Benedict zakłada, że do kultur „winy” zalicza się te, w których ocena moralna opiera się na wewnętrznym systemie wartości, a nie na ocenie sugerowanej przez grupę społeczną. Do kultur ,winy” zalicza kulturę zachodnią. Natomiast w kulturze „wstydu” ocena moralna jest zależna od osądu społecznego popełnionego czynu. Kulturę chińską zalicza zatem do kultur „wstydu”. Tego typu założenie jest ogromnie krzywdzące dla przedstawicieli kultury chińskiej, bowiem odbiera jednostce jakąkolwiek podmiotowość w ocenie moralnej popełnionego przez nią czynu. Rozróżnienie to uzasadnia się także poprzez psychologiczne teorie rozwoju moralnego. Najczęściej cytowana jest teoria rozwoju moralnego Kohlberga, zgodnie z którą wraz z dojrzewaniem jednostka przechodzi kolejne fazy przestrzegania kodeksu moralnego z powodu: strachu przed karą - własnych korzyści - nagród znajomości prawa - korzyści społecznych - uniwersalnych zasad moralnych. Biorąc pod uwagę teorię przedstawicieli kultury chińskiej, jako że przez całe życie mają na uwadze także dobro grupy i z tego powodu nigdy nie osiagają poziomu szóstego, na którym oceny moralne są całkowicie niezależne od wpływu grupy, określa się jako niedojrzałych moralnie. Analogicznie można by przedstawicieli zachodniej kultury uznać za niedojrzałych w świetle chińskich koncepcji rozwoju moralnego, według których o dojrzałości świadczy stopień wrażliwości na oceny społeczne. Niestety, w dyskusjach na temat moralności często nie bierze się pod uwagę zgodności teorii z rzeczywistością. Liczne badania, prowadzone na gruncie psychologii rozwojowej, pokazują bowiem, że zdecydowana większość przedstawicieli kultury zachodniej zatrzymuje się w swoim rozwoju na trzecim etapie klasyfikacji Kohlberga! Sam Kohlberg przyznaje, że zaledwie $20 \%$ populacji osiaga szósty poziom rozwoju moralnego. W ten sposób mamy do czynienia z pewnego rodzaju paradoksem - skoro Chińczycy w swojej ocenie moralnej kierują się normami, które są korzystne dla społeczeństwa, to można na tej podstawie wysnuć wniosek, że większość
} 
rozróżnienie, co jest, a co nie jest kłamstwem). W kulturze chińskiej nie występuje typowe dla kultury zachodniej pokrywanie się etykiety kłamstwa $\mathrm{z}$ etykieta grzechu i zła, tym samym Chińczykom łatwiej jest zamienić etykietę kłamstwa na prawdę, gdy kłamstwo pojawia się w sytuacji prospołecznej. W kulturze zachodniej, tak jak w kulturze chińskiej, nie negocjuje się społecznie samej etykiety kłamstwa i prawdy. Jednak tym, co różni kulturę zachodnią od chińskiej jest brak negocjowania oceny moralnej kłamstwa społecznie. Jeżeli kłamstwo jest identyfikowane $\mathrm{z}$ grzechem, to właściwie zawsze jest negatywnie oceniane, zarówno przez jednostkę, jak i przez grupę. Badania potwierdzają daną tezę. Kanadyjskie dzieci i dorośli są zgodni, co jest kłamstwem, a co prawdą. Zgodni są także co do oceny moralnej prawdy i kłamstwa. Bez względu na kontekst sytuacyjny kłamstwo zawsze jest przez nich oceniane negatywnie. Oczywiście zaobserwowano, tak jak w przypadku dzieci chińskich, wpływ procesu socjalizacji na oceny moralne. Wraz $\mathrm{z}$ wiekiem dzieci kanadyjskie coraz bardziej negatywnie oceniają kłamstwo, również to, które pojawia się w kontekście prospołecznym. Zatem ma miejsce proces odwrotny do tego, który zaobserwowano w Chinach (!). Podkreślam jednak, że cały czas mówimy o kłamstwie w sytuacji prospołecznej, natomiast kłamstwo w innych sytuacjach jest tak samo negatywnie oceniane, zarówno w kulturze kanadyjskiej, jak i chińskiej. Zgodność etykiety wybranej przez jednostkę $\mathrm{z}$ etykietą wybraną przez grupę $\mathrm{z}$ pewnością wynika także z faktu, że kultura zachodnia swoją koncepcję prawdy opiera na jej zgodności z rzeczywistością, którą można udowodnić za pomocą dowodów natury rozumowej i empirycznej. Skoro prawdę można udowodnić, to istnieje większe prawdopodobieństwo niż w przypadku prawdy sugerowanej - jak ma to miejsce w kulturze chińskiej - że etykiety wybrane przez jednostkę i grupę będa pokrywać się. Poza tym w kulturze zachodniej większe znaczenie niż zachowanie harmonii w grupie odgrywa prawo do uzyskania informacji. W kulturze zachodniej przyjmuje się także, że o ocenie moralnej oprócz prawa do uzyskania informacji decyduje także wolność wyboru i zdrowie psychiczne.

\section{Podsumowanie - nieporozumienia międzykulturowe wynikające z błędnej interpretacji odmiennych koncepcji kłamstwa}

Dyskusja, który ze sposobów postrzegania świata jest bardziej wartościowy nie ma sensu. Uważam, że rozsądniej jest skupić się na tym, co sprawia, że są

Chińczyków osiąga piąty poziom rozwoju moralnego według Kohlberga. Jak widać, badanie obcej kultury za pomocą narzędzi, będących produktem własnej kultury prowadzi zazwyczaj do szeregu nieporozumień. Patrz: K. C h m i e 1 e c k a, Różnice kulturowe $w$ sposobie oceny $i$ etykietowania kłamstwa w Polsce i Chinach, Szkoła Wyższa Psychologii Społecznej, Warszawa 2007 (niepublikowana praca magisterska). 
tak bardzo odmienne. System moralny jest elementem kultury ${ }^{31}$, najbardziej odpornym na jakiekolwiek zmiany i wpływy z zewnątrz. Siła i niezmienność klasycznej koncepcji kłamstwa - preferowanej w kulturach zachodnich - wynika $\mathrm{z}$ jej zakotwiczenia zarówno $\mathrm{w}$ filozofii, jak i w religii. Ze względu na pokrywanie się na zachodzie etykiety kłamstwa i grzechu, jakakolwiek dyskusja czy poddanie pod osąd kłamstwa jest postrzegane jako niemoralne. Dyskusja na temat kłamstwa nie ma właściwie szansy na wyjście poza obszar etyki i teologii. Nawet w przypadku prac przekrojowych, dotyczących problematyki kłamstwa, już na wstępie sugeruje się czytelnikom, jaka definicja kłamstwa jest tą właściwą, którą należy przyjąć jeżeli jest się przedstawicielem kultury zachodniej. Przykładem takiej praktyki może być sugestia autora, która pojawia się już w prologu Filozofii kłamstwa, a brzmi następująco: „Dlaczego twierdzimy już w Prologu, że należy wybrać prawdę w sensie klasycznym? ${ }^{32}$ Albowiem tylko w niej o wartości poznania rozstrzyga intelekt jednostkowej osoby. Tylko w tej koncepcji gwarantem obiektywności prawdy jest zgodność z rzeczywistością. Bez względu na ilość i rodzaj presji wywieranej na nas, musimy oprzeć własne przekonanie o prawdzie - na rozpoznaniu rzeczywistości, na tym, jaka jest naprawdę". W kulturze chińskiej dyskusja na temat kłamstwa także nie jest aprobowana, może bowiem przyczynić się do naruszenia harmonii w relacjach międzyludzkich. W kulturze chińskiej oskarżenie o kłamstwo wiąże się z o wiele dalej idącymi konsekwencjami niż w kulturze zachodniej. Może oznaczać utratę twarzy zarówno przyłapanego na kłamstwie, jak i oskarżającego o nie. Tego typu oskarżenie prowadzi do utraty twarzy nie tylko w sensie społecznym, lecz także moralnym ${ }^{33}$. W kulturze chińskiej dopuszczalne jest kłamstwo, jeżeli ma wymiar prospołeczny. Jednak nie rozmawia się na jego temat otwarcie. Ważny jest efekt, a nie środki, które doprowadziły nas do celu. Jeżeli nikt nie stracił

${ }^{31}$ Choć w kulturze zachodniej nadal pojawiają się głosy, że istnieje tylko jedna moralność wszystkim ludziom wspólna, to pamiętać należy, że mimo zachodniego absolutyzmu moralnego już w 1688 r. Samuel Pufendorf w pracy De iure naturae et gentinum posługuje się terminem cultura na oznaczenie nie tylko instytucji społecznych, mody czy języka, lecz także moralności, kierowanej przez rozum i obyczaje. Zatem myślenie o moralności jako wytworze kultury nie jest całkowicie obce kulturze zachodniej; http://wiki.grafita.pl/link-Kultura (stan z 28.09.2007).

${ }^{32}$ Tytuł podrozdziału brzmi bowiem: „Prymat klasycznej koncepcji kłamstwa”.

${ }^{33} \mathrm{~W}$ kulturze chińskiej funkcjonują dwie koncepcje twarzy: mian i lian. Mian wiąże się z szacunkiem dla zasad współżycia jednostki ze społeczeństwem, natomiast lian dotyczy przestrzegania zasad moralnych, dzięki którym dana jednostka w ogóle ma szansę zaistnieć w danym społeczeństwie. Zatem można powiedzieć, że lian to 'twarz moralna' a mian to 'twarz społeczna'. Jako, że mian jest konstruowana społecznie, jej odzyskanie jest także zależne od przyzwolenia społeczeństwa, natomiast utrata lian jest identyfikowana z utratą człowieczeństwa. Lian jest właściwie niemożliwa do odzyskania, a jej utrata wiąże się z wykluczeniem z grupy lub nawet ostracyzmem społecznym. Ponieważ lian jest fundamentem mian, utrata lian wiąże się zatem jednoznacznie z utratą mian; [za:] J. W e n s h a n, The Remaking of the Chinese Character and Identity in the 21st Century, Ablex Publishing, London 2001. 
twarzy, nie została zaburzona hierarchia społeczna, to nie ma sensu dyskusja na temat kłamstwa, które zapobiegło potencjalnej katastrofie. Buddyzm stawia kłamstwo wśród dziesięciu najbardziej nieakceptowanych złych uczynków. Tak jak w religii chrześcijańskiej, tuż obok kłamstwa wymienia się zabójstwo czy kradzież. Zatem kłamstwo zarówno w kulturze zachodniej, jak i chińskiej nie jest aprobowane. Różnica jednak polega na percepcji kłamstwa, a właściwie na percepcji jego konsekwencji. Ponieważ dyskusja na temat kłamstwa stanowi pewnego rodzaju tabu, utrudniona jest wymiana informacji na temat różnych sposobów postrzegania kłamstwa, a nawet uświadomienie sobie podłoża percepcji danego zjawiska we własnej kulturze. Brak wiedzy na temat odmiennego sposobu postrzegania kłamstwa w obu kulturach przyczynia się do powstawania wielu nieporozumień na styku obu kultur. Myślę, że dobrym przykładem może być percepcja Sztuki wojny Sun Tzu w kulturze zachodniej. Otóż została ona przetłumaczona na język francuski dopiero $\mathrm{w}$ drugiej połowie XVIII w. i spotkała się z bardzo nieprzychylnym przyjęciem w kręgu kultury zachodniej. „Niezwiązani z wojskowością zachodni czytelnicy szczególnie piętnowali Sun Tzu za dosadność twierdzeń, które są sprzeczne z ich tradycją traktowania szpiegostwa, i z perspektywy doktryny chrześcijańskiej potępiali zalecane w Sztuce wojny praktyki jako postępowanie pogańskie" ${ }^{, 34}$. Mimo że strategie walki Sun Tzu zaadaptowano na zachodzie nie tylko na gruncie militarnym, lecz także $\mathrm{w}$ dziedzinie polityki, zarządzania i sportu, to nadal spotykają się z błędną interpretacją. Przykładem wypaczonej zachodniej interpretacji Sztuki wojny może być artykuł na temat incydentu, jaki miał miejsce podczas mundialu w 2006 r., gdy francuski piłkarz został sprowokowany przez portugalskiego i uderzył go podczas finałowego meczu. Oto fragment artykułu:

[...] sadystyczne skłonności trzeba przypisać niemal wszystkim piłkarzom. Przecież nagrodę dla najbardziej atrakcyjnej drużyny mundialu otrzymali Portugalczycy, najbardziej nieznośni wśród finalistów turnieju, którzy podczas gry dopuszczają się mnóstwa małych prowokacji, niedostrzegalnych dla sędziego fauli i w ogóle korzystają z bogatego arsenału brudnych chwytów, by zniechęcić bardziej uzdolnionych rywali do gry w piłkę. Trener Scolari rozdaje im podręcznik bitewnej strategii chińskiego klasyka Sun Tzu, uparcie nazywa mecz piłkarski <wojną>, mnóstwem drobnych świństewek próbuje wydobywać z przeciwnika jego najgorsze cechy ${ }^{35}$.

Nie widzę związku pomiędzy zaleceniami Sun Tzu a awanturami, które mają miejsce podczas meczów piłki nożnej. Zachowanie piłkarzy świadczy raczej o ich braku kontroli nad własnymi emocjami niż o przemyślanej strategii walki. Niestety, o Sztuce wojny najczęściej mówi się na zachodzie jako o wskazówkach, jak oszukać, okłamać, zmylić i wyprowadzić w pole przeciwnika. Świad-

\footnotetext{
${ }^{34}$ S u n $\quad$ T z u, Sztuka wojny, przeł. D. Bakałarz, Wydawnictwo Helion, Gliwice 2004, s. 136.

${ }^{35}$ R. S t e c, Zinadine Zidane bohater naszych czasów, „Gazeta Wyborcza”, 11.07.2006.
} 
czyć mają o tym fragmenty typu: „Działania armii opierają się na podstępach”, „Wojna jest Tao wprowadzania w błąd. Jeśli zatem jesteś zdolny, udawaj mało zdolnego. Gdy podrywasz swoje wojsko do działania, udawaj bierność. Jeżeli twój cel jest bliski, zachowaj się tak, jakby był odległy. A gdy jest odległy, udawaj, że jest bliski”, „Udawajcie niezdolnych do walki, a nieprzyjaciel na pewno nadejdzie. Zastawcie zasadzki, ukryjcie się $\mathrm{w}$ trawie $\mathrm{i}$ atakujcie $\mathrm{w}$ niespodziewanym momencie. Wtedy możemy odnieść sukces" itd. Jednak już rzadko zwraca się uwagę na kontekst, w jakim zostały wypowiedziane dane słowa. Wyliczamy kłamstwa i podstępy, natomiast Chińczycy zwracają uwagę na cel, jakiemu służą określane taktyki. Dla nas liczy się przede wszystkim wygrana (gdy wygrywamy, nieistotne są już koszty, z jakimi się ona wiąże), natomiast dla Chińczyków ogromnie istotne są wszystkie konsekwencje, jakie wiążą się z wygraną. Nie jest sztuką wygrać raz - to może być po prostu łut szczęścia - sztuką jest taka wygrana, która pozwala zachować potencjał niezbędny do przystapienia do kolejnej walki. Poza tym Sztuka wojny to nie jest jedynie ,arsenał brudnych chwytów”, lecz także głęboko humanitarna koncepcja walki. Sun Tzu wielokrotnie zwraca uwagę, że należy walczyć tak, aby wygrać przy jak najmniejszej liczbie strat po stronie własnej armii, ale także armii wroga. Sun Tzu powiedział:

Generalnie metoda prowadzenia wojny jest taka: najlepiej zachować stolicę wroga, bo jej zniszczenie jest gorszym wyjściem. Najlepiej ocalić jego armię, bo jej zniszczenie jest gorszym wyjściem. Najlepiej ocalić jego bataliony, bo ich zniszczenie jest gorszym wyjściem. Najlepiej ocalić jego kompanię, bo ich zniszczenie jest gorszym wyjściem. Najlepiej ocalić jego jednostki, bo ich zniszczenie jest gorszym wyjściem. Dlatego sto zwycięstw w stu bitwach nie jest szczytem osiągnięć. Prawdziwym szczytem osiągnięć jest podbicie armii bez walki ${ }^{36}$.

Podstęp czy kłamstwo są rozumiane jako sposób na uniknięcie walki lub zminimalizowanie jej negatywnych konsekwencji. Według Chińczyków, nie ma nic złego we wprowadzeniu przeciwnika w błąd, jeżeli w ten sposób można szybciej zakończyć wojnę i ocalić więcej ludzi, zarówno po stronie własnej armii, jak i po stronie przeciwnika. Taki sposób patrzenia na walkę nie mieści się w ramach zachodniego sposobu myślenia o wojnie. Dla przedstawicieli kultury zachodniej najtrudniejsza do zaakceptowania jest świadomość bycia okłamanym czy oszukanym. Nie liczy się dla nas w takiej sytuacji kontekst czy cel wprowadzenia w błąd. Naszą uwagę przykuwa przede wszystkim fakt, że ktoś dopuścił się kłamstwa, a tym samym złamał jedną z podstawowych zasad interakcji międzyludzkich, wyznaczonych przez filozofię chrześcijańską. Kłamstwo postrzegamy jako rodzaj przemocy i wykorzystania. Okłamanie kogoś można porównać do pozbawienia go czegoś wartościowego (łac. deceive $=d e+$ capere $=$ 'chwycić, brać'). Według Loyala Rue, to właśnie „lęk przed byciem

\footnotetext{
${ }^{36}$ Sztuka wojny, s. 70.
} 
oszukanym ukształtował tradycję intelektualną i moralną kultury zachodniej”,37. W swojej pracy zatytułowanej By the Grace of Guile przedstawia historie formowania się zachodniej obsesji na punkcie bycia oszukiwanym, od starożytnej myśli filozoficznej, poprzez średniowieczne procesy o czary, renesansową koncepcję sztuki, reformację, aż po egzystencjalizm i współczesne koncepcje zdrowia psychicznego i postępu społecznego. Na podstawie analizy faktów historycznych i ich wpływu na uformowanie się współczesnej koncepcji kłamstwa Loyal Rue dochodzi do wniosku, że ,zachodnią tradycję uformowała bardziej walka z oszukiwaniem i kłamstwem, aniżeli pytanie o oczywistość i pewność prawdy" ${ }^{\text {"3 }}$. O tym, że współczesny sposób postrzegania kłamstwa przez kulturę zachodnią niewiele różni się od sposobu, w jaki było postrzegane chociażby w średniowieczu, świadczyć mogą współczesne badania dotyczące tej problematyki. Zdecydowana większość badań i publikacji poświęcona jest następującym zagadnieniom: jak zdemaskować kłamcę, jak nie stać się ofiarą kłamstwa, kto i jak często kłamie. Publikacje poświęcone przyczynom psychologicznym, społecznym, kulturowym czy historycznym kłamstwa stanowią rzadkość na rynku wydawniczym. $Z$ artykułów na temat kłamstwa możemy natomiast się dowiedzieć, że „większość ludzi kłamie raz lub dwa razy dziennie”, „w ciaggu tygodnia oszukujemy około $30 \%$ ludzi, z którymi wchodzimy w interakcję”, ,,na randce kłamiemy w przypadku co trzeciej wypowiedzi”, „w małżeństwie $10 \%$ codziennych wypowiedzi jest kłamstwem”, „tylko $8 \%$ badanych twierdzi, że nigdy nie kłamie” oraz ,wszyscy badani byli przekonani, że częściej są oszukiwani aniżeli oszukują"39 (!). Zachodnia obsesja na punkcie bycia potencjalną ofiarą oszustwa sprawia, że zanim jeszcze ktoś nas oszuka, jesteśmy skłonni postrzegać daną osobę jako potencjalnego kłamcę. Jednak tym, co przede wszystkim zwróciło moją uwagę $\mathrm{w}$ publikacjach poświeconych problematyce kłamstwa są wyniki badań pokazujące, że nie ma takiej kultury, w której ludzie nie kłamią. Zatem zamiast zastanawiać się, kto kłamie i kto częściej to robi bardziej rozsądne wydaje się podjęcie dyskusji, dotyczącej przyczyn warunkujących kłamstwo i ich wpływu na sposób postrzegania kłamstwa w różnych kulturach. Oczywiście nie twierdzę, że musimy zmienić swój system wartości, co zresztą z perspektywy dotychczasowych doświadczeń zachodu wydaje się całkowicie absurdalne. Wschodni holizm potrafimy zaakceptować - przynajmniej w pewnym stopniu w medycynie, o czym świadczy coraz większa popularność, jaką cieszy się medycyna chińska na zachodzie. Oszukiwać pozwalamy się jednak jedynie sztuce $^{40}$. Jestem jednak przekonana, że bez próby zrozumienia obcej nam

\footnotetext{
${ }^{37}$ L. Rue, By the Grace of Guile, Oxford University Press, Oxford 1994.

${ }^{38}$ Ibidem, s. 6.

${ }^{39}$ Wyniki badania Bella DePaulo cyt. za: A. K o r n e t, The Truth About Lying. Has Lying Gotten a Bad Rap?, „Psychology Today”, May/June 1997, s. .

${ }^{40}$ „W starożytności pseudos, oznaczające kłamstwo (i do dziś służące do wskazywania różnych rodzajów nieprawdziwości, jak w określeniu «pseudo-intelektualista»), bywało używane
} 
perspektywy filozoficznej nigdy nie zostanie przełamany brak zaufania, ciążący na kontaktach przedstawicieli kultury zachodniej z chińską. Osoby głęboko wierzące, że wpływ zachodu zarówno w obszarze etyki, jak i prawa z czasem zmieni chińską koncepcję kłamstwa muszę rozczarować. Badania dotyczące kłamstwa, przeprowadzone na Tajwanie i w $\mathrm{Chinach}^{41}$, wyraźnie pokazują, że to nie Chiny, które dopiero otwierają się na wpływy z zewnątrz, ale Tajwan jest bardziej wierny tradycji konfucjańskiej ${ }^{42}$. Zatem rozsądniejsza wydaje się propozycja podjęcia studiów nad kulturą chińską niż bezpodstawna wiara w dominację zachodniego systemu wartości. Oczywiście owo wyzwanie dotyczy obu stron - zarówno zachodniej, jak i chińskiej - bowiem przedstawiciele kultury zachodniej i kultury chińskiej postrzegają postępowanie swoich partnerów jako niemoralne.

również w znaczeniu pomyłki, błędu, fałszu i iluzji, zwłaszcza w odniesieniu do sztuki, gdzie ma miejsce zastępowanie mimetyczne"; [za:] W. C h u d y, op. cit., s. 11.

${ }^{41} \mathrm{~K}$ a n g L e e, et al., op. cit., s. 525-542.

${ }^{42}$ Mimo że na Tajwanie w 1997 r. wycofano program dotyczący edukacji moralnej dzieci, nie zmienił się stosunek mieszkańców Tajwanu do podstawowych wartości konfucjańskich. W Chinach nadal istnieje program uczący dzieci „Pięciu Cnót”, do których należy skromność i mówienie prawdy, jednak w Chinach nie przywiązuje się tak dużej wagi do skromności jak na Tajwanie. Różnica wynika z nieco odmiennych wartości, jakie stanowią o kolektywizmie w Chinach i na Tajwanie. Chiński kolektywizm jest bowiem mieszanką wartości konfucjańskich i ideologii komunistycznej. Ideologia maoistyczna osłabiła konfucjański system wartości. Tajwan odrzucił komunistyczną ideologię i praktykował konfucjanizm w pierwotnej formie (konfucjanizm został uznany za religię narodową Tajwanu już po II wojnie światowej). Zatem to nie kontakt z kulturą zachodnią (Tajwan), ale wewnętrzne zmiany (Chiny) mają największy wpływ na zmiany systemu wartości. 